\title{
List więzienny w świetle rygorów cenzury. Rekonesans
}

\section{Prison Letters in Light of Censorship: A Reconnaissance}

\begin{abstract}
This article is a preliminary survey of the prison epistolography of political prisoners from the time of the Polish People's Republic. By analysing published prison letters of Czesław Bielecki, Gaja and Jacek Kuroń, as well as letters addressed to Izabela Jarosińska the author elucidates the influence of censorship on the form and subject matter of prison correspondence. Stanisław Barańczak's typology of limitations imposed on the prison letter by censorship, as well as Marta Fik's notion of the censor as co-author, constitute a crucial reference point for the current analysis. The article also examines the frequency of prison communication, the material aspect (appearance) of the letter, its volume, and the restrictions in choosing the addressee; an attempt is also made to delimit the "safe" thematic boundaries, which the imprisoned could navigate in their epistolary writings. Finally, a characteristic is provided of the specific strategies adopted in the fight with censorship, particularly focusing on the methods of outsmarting the censor, such as coding information by means of metaphors and allusions or through the use of Aesopian language.
\end{abstract}

Keywords: prison letters, literature of personal documents, democratic opposition, Polish People's Republic, censorship

Streszczenie: Artykuł stanowi przyczynek do badań nad epistolografią więzienną więźniów politycznych okresu PRL. Na przykładzie wydanych zbiorów listów więziennych Czesława Bieleckiego, Gai i Jacka Kuroniów oraz listów wysyłanych do Izabeli Jarosińskiej omówiono wpływ cenzury na kształt i tematykę więziennych korespondencji. Punktem wyjścia dla autora była typologia cenzorskich ograniczeń listu więziennego zaproponowana przez Stanisława Barańczaka oraz koncepcja cenzora-współautora Marty Fik. W tekście omówiono: częstotliwość więziennej komunikacji, materialność (wygląd) listu, objętość, ograniczenia w wyborze adresata, wreszcie podjęto próbę zarysowania „bezpiecznych” obszarów tematycznych, po których mogli się poruszać więzienni epistolografowie, jak również scharakteryzowano strategie walki z cenzurą, zwracając uwagę na takie metody gry z cenzorem, jak kodowanie informacji za pomocą metafor i aluzji czy język ezopowy.

Słowa kluczowe: list więzienny, literatura dokumentu osobistego, opozycja demokratyczna PRL, cenzura 


\section{Wstęp}

Kiedy chcemy opisać relacje między korespondującym z celi więźniem politycznym a bliską mu osobą pozostającą na wolności lub dzielącą z nim los więźnia, nie możemy zapomnieć o trzecim uczestniku tej „intymnej” pisemnej wymiany myśli - cenzorze. Można nawet sądzić, że w tej hierarchii to on stanowi wierzchołek „czytelniczego trójkąta”. Cenzor - a niekiedy nawet sama świadomość jego obecności - w zasadniczy sposób wpływał na treść listów, zakłócał ich nominalnie prywatny charakter, wprawiał piszących w kłopot, a nawet uczucie beznadziei. Ale adresatów listów więziennych - jak się zdaje - było jeszcze więcej. Sądzę, że piszącym z celi więźniom politycznym musiała towarzyszyć mniejsza lub większa świadomość, że te w pewnym sensie wciąż intymne zapiski mają wartość historyczną i publiczną - dokumentują bowiem szczególny okres historii, wyrażają fragment losu dysydenta. Adresując listy do najbliższych, adresowali je poniekąd do całego wolnego świata, także do przyszłych czytelników. Zapewne autorzy listów gdzieś z tyłu głowy mieli świadomość, że to, co piszą, posłuży kiedyś jako dokument historyczny, a zatem i publiczny.

O przyszłej recepcji listów z więzienia pisał w eseju Horyzont absolutny Stanisław Barańczak, który przewidywał, że za kilka stuleci list z więzienia będzie uważany przez historyków literatury za jedną z najbardziej kunsztownych odmian literatury. Szanse na to upatrywał w analizie sposobów, za pomocą których piszący „igra z narzuconymi mu ograniczeniami” ${ }^{1}$. Dziś trudno jeszcze patrzeć na więzienną korespondencję wyłącznie w kategoriach estetycznych. Niemniej jednak chyba nadszedł czas na to, żeby głębiej przyjrzeć się tej osobnej części polskiej epistolografii.

W niniejszym tekście postaram się wskazać główne obszary cenzorskiego panowania nad listem pisanym z więziennej celi. Dokonam analizy wpływu cenzury na korespondencję z zastrzeżeniem, że opieram się głównie na kilku opublikowanych wyborach listów więźniów politycznych PRL, zatem owa analiza będzie się odnosić prawie wyłącznie do epistolografii więziennej pisanej od lat sześćdziesiątych do osiemdziesiątych XX wieku w Polsce. Stawiam tu przed sobą dwa zadania: po pierwsze, scharakteryzować te obszary działalności cenzury, które znajdują odzwierciedlenie w korespondencjach więźniów politycznych; po drugie, zasygnalizować pewne strategie radzenia sobie z cenzurą, które stosowali piszący. Żeby to uczynić, sięgnąłem po literaturę odnoszącą się wprost do epistolografii więziennej, ale przede wszystkim wykorzystałem wcześniejsze badania cenzury PRL, które dotyczyły tekstów literackich i artystycznych.

${ }^{1}$ S. Barańczak, Horyzont absolutny [w:] tegoż, Tablica z Macondo. Osiemnaście prób wyttumaczenia, po co i dlaczego się pisze, Londyn 1990, s. 120. 


\section{Cenzor jako współautor}

Istnienie i działalność cenzury ma zasadniczy wpływ na list więzienny. Przede wszystkim cenzor, obok nadawcy, jest często jedyną osobą, która czyta list $\mathrm{w}$ jego integralnym kształcie ${ }^{2}$. Oznacza to, że nie tylko jest intruzem wkraczającym w intymny świat korespondujących, ale wręcz współautorem. Nie jest to wszak odkrycie nowe. Zaproponowała je już Marta Fik w artykule zatytułowanym właśnie Cenzor jako wspótautor. Analizując przykłady działalności cenzora w odniesieniu do literatury, filmu czy teatru, Fik traktowała współautorstwo jako jedną z jego funkcji. Wykazała też wszechwładzę cenzora, pisząc, że był on nadzorcą i weryfikatorem, doradcą i niemal prokuratorem ${ }^{3}$. Wydaje się, że w odniesieniu do epistolografii więziennej cenzor ma jeszcze większą władzę. Wynika to przede wszystkim z mniejszej odpowiedzialności za ewentualne przeoczenia. Przepuszczenie w liście więziennym niepożądanego fragmentu nie było - z punktu widzenia władzy - tak szkodliwe społecznie, jak uczynienie tego samego w literaturze i filmie, trafiających do szerokiego audytorium. Ponadto cenzor więziennej korespondencji nie miał nad sobą zwierzchników (w przeciwieństwie do cenzorów zajmujących się literaturą piękną). O ile cenzor listów więziennych de facto "wydawał wyrok" na list, o tyle cenzor utworów literackich mógł jedynie opiniować wymowę dzieła i jego kształtu ${ }^{4}$. Ta wszechwładza cenzora więziennej korespondencji mogła działać dwojako. Z jednej strony mógł on okazać swą łaskawość i przepuszczać kontrowersyjne fragmenty, z drugiej wykreślać dowolne części właściwie bez podania przyczyny. Aleksander Pawlicki w książce o cenzurze w PRL twierdził, że cenzor to „destruktor, ale subiektywnie przekonany o tym, że współtworzy"s. Anonimowy cenzor w wywiadzie udzielonym Joannie Pruszyńskiej - zagadnięty o „współautorstwo” - tłumaczył, że normalnie myślący cenzor „musiał mieć świadomość tego, że kaleczy i umniejsza tekst" ${ }^{\text {" }}$. Trudno obecnie stwierdzić, które z tych zdań bardziej oddaje świadomość cenzora listów więziennych. Szczególnie, że prawdopodobnie nie miał on świadomości obcowania z summa summarum tekstem literackim. Nie zwalniało go to jednak od odpowiedzialności za ostateczny kształt listu.

2 Zob. K. Budrowska, Literatura i pisarze wobec cenzury PRL (1948-1958), Białystok 2009, s. 16.

${ }^{3}$ M. Fik, Cenzor jako wspótautor [w:] Literatura i wtadza, red. B. Wojnowska, Warszawa 1996, s. $134-135$.

${ }^{4}$ K. Budrowska, dz. cyt., s. 93-94 i n.

5 A. Pawlicki, Kompletna szarość. Cenzura w latach 1965-1972. Instytucja i ludzie, Warszawa 2001, s. 85.

6 Sam na sam z Polska Ludowa. Z cenzorem rozmawia J. Pruszyńska, „Rzeczpospolita” $15-16.04 .2000$. 


\section{Ograniczenia listu więziennego}

Przywoływany tu już tekst Barańczaka posłużył jako wstęp do korespondencji więziennej Václava Havla. Autor wymienia w nim wiele restrykcji, z którymi czeski dysydent musiał się zmagać podczas pisania listów do żony. Są to kolejno: ograniczenie częstotliwości wypowiedzi, rozmiaru tekstu, wyboru adresata, tematu, tonu listu, słownictwa, charakteru pisma odręcznego, a nawet interpunkcji i graficznego kształtu listu. Barańczak ma również świadomość innych licznych samoograniczeń, wypływających z „czujnej obecności cenzorskiego spojrzenia"'. Oczywiście już pobieżne zestawienie korespondencji Havla z listami więźniów politycznych okresu PRL (1965-1989) - mam tu na myśli głównie korespondencje Gai i Jacka Kuroniów, Czesława Bieleckiego czy Izabeli Jarosińskiej - wskazuje na odmienność zasad panujących w czechosłowackim i polskim systemie więziennej cenzury tamtego okresu. Nie zmienia to faktu, że polski więzień epistolograf musiał się mierzyć z podobnymi ograniczeniami co jego czechosłowacki odpowiednik.

Częstotliwość komunikacji za pomocą listu więziennego w warunkach polskich lat 1965-1989 była zmienna i zależała głównie od statusu więźnia. Status więźnia śledczego, a takim był każdy osadzony do momentu ogłoszenia wyroku, umożliwiał aresztowanemu częstszy kontakt z najbliższymi. Miał on prawo do czterech listów w miesiącu. Sytuacja na jego niekorzyść zmieniała się po ogłoszeniu wyroku. Wówczas więźniowi przysługiwały dwa listy w miesiącu ${ }^{8}$. Ponadto istniały przypadki nakładania kar w postaci tymczasowego zakazu korespondencji, które zaburzały, a nawet czasowo uniemożliwiały wymianę listów. Dwumiesięczny zakaz korespondencji i widzeń został w 1966 roku nałożony na Kuronia za handel rzeczami osobistymi. Trzy lata później w więzieniu we Wronkach Kuroń został ukarany dwumiesięcznym zakazem widzeń za to, że próbował wynieść herbatę z pralni do celi ${ }^{10}$. O podobnej karze wspomina również inny więzień - Czesław Bielecki ${ }^{11}$. Jak zatem widać, poważne konsekwencje w postaci wstrzymania korespondencji czekały więźniów za relatywnie drobne przewinienia. A jednak Bielecki, pomimo nałożonej sankcji, nie zaprzestał praktyki regularnego pisania listów. Pokazuje to, że czynność ta w warunkach odosobnienia przekształciła się w pewien rytuał więziennego życia.

7 S. Barańczak, dz. cyt., s. 122.

${ }^{8} \mathrm{O}$ zmianie tej w jednym z listów pisze Jacek Kuroń. Zob. G. i J. Kuroniowie, Listy jak dotyk, Warszawa 2014, s. 52.

9 Zob. tamże, s. 109.

10 Zob. tamże, s. 192.

11 Zob. C. Bielecki, Z celi do celi. Listy do żony, Londyn 1990, s. 72. 
Zakłócenia regularności korespondencji nie tylko wypływały z oceny zachowania więźniów, ale także miały związek z trybem jej przepływu. List pisany z więziennej celi lub do niej, zanim trafił do adresata (jeśli nie został wstrzymany czy odesłany z powrotem do „autokorekty”), przechodził dość długą, choć nie tak znów skomplikowaną drogę. Przepływ korespondencji przedłużony był ze względu na pracę cenzora. Czas tego postoju trwał od dwóch tygodni do nawet dwóch miesięcy. Zaburzało to rzecz jasna naturalną wymianę korespondencji. Kolejne listy osadzonego nie zawsze były odpowiedzią na poprzedni list osoby na wolności i odwrotnie. $Z$ uwagi na to piszący dość często rozpoczynali swoje listy od informowania, które adresowane do nich przesyłki dotarły. Wprowadzali również zasadę numerowania listów. Ważnym odkryciem osób przebywających na wolności było to, że zaniesienie listu wprost do prokuratury znacznie przyspieszało jego drogę do adresata. Informuje o tym nie tylko Izabela Jarosińska w wydanym wyborze korespondencji, którą otrzymywała jako więźniarka polityczna w latach 1985-1986 ${ }^{12}$. Potwierdzenie tego znajdziemy też w listach Grażyny Kuroń ${ }^{13}$.

Nie tylko kary czy opieszałość cenzora zakłócały regularną cyrkulację korespondencji. Jednym z czynników, oczywiście pośrednio wynikającym z istnienia i wszechwładzy cenzury, były „błędy” popełnianie przez autora. Mam tu na myśli wszystkie te nieprawomyślne fragmenty, które zwracały uwagę cenzury i powodowały różnego rodzaju konsekwencje. Zdecydowanie najłagodniejsza z nich to zwrócenie listu autorowi do ponownego przepisania z zastosowaniem się do uwag. Praktyki takiej doświadczył Bielecki ${ }^{14}$. Przykład ten ilustruje jedną z bardziej charakterystycznych funkcji cenzury, w pewnym sensie "dydaktyczną", bowiem miała ona na celu nauczyć autocenzury skazanych i korespondujących z nimi bliskich. Powodowało to jednak niekiedy wycofywanie się piszących z chęci przekazania jakiejś informacji czy rozwinięcia wątku. Inną, najczęstszą i nieodwracalną formą ingerencji cenzorskiej było skreślanie i wymazywanie niepożądanych słów, zdań czy zwrotów, co ma związek z materialnością listu, o czym napiszę niżej. Ale zdarzały się poważniejsze w skutkach przypadki zarekwirowania listu i włączenia go do akt śledztwa. Przytrafiło się to między innymi Bieleckiemu, który w liście do żony przytacza dość osobliwe uzasadnienie, jakie otrzymał. List został zarekwirowany „w związku z umieszczeniem w nim złośliwych komentarzy na temat warunków w areszcie oraz cytatów zawierających pochwałę faszyzmu włoskiego" ${ }^{15}$. W związku z tym Bielecki niekiedy przepisywał $\mathrm{w}$ kolejnym liście fragmenty z poprzednich zatrzymanych

12 Ocenzurowane. Listy do więzienia 1985-1986, wybór i oprac. I. Jarosińska, Warszawa 2012, s. 20.

13 Por. listy Gai z: 25 V 1977 r., 14 VI 1977 r. [w:] G. i J. Kuroniowie dz. cyt., s. 222, 225-226, 229-230.

${ }_{14}$ C. Bielecki, dz. cyt., s. 11-12.

15 Tamże, s. 51. 
bądź odesłanych z powrotem do autokorekty listów, które nazywał „bisami”. Ponadto Jarosińska informuje o przerwach korespondencji w okresach kryzysowych, na przykład w czasie awarii reaktora jądrowego w Czarnobylu ${ }^{16}$. Kłopoty z przepływem korespondencji miały też przełożenie na motywacje piszących. Podczas swojej pierwszej odsiadki Kuroń tłumaczył żonie powody przerw w pisaniu niepewnością, czy listy do niej docierają ${ }^{17}$.

Materialność listu więziennego. Paweł Rodak w swojej książce o dziennikach stwierdza, że badanie diariuszy pisarzy w ich oryginalnej postaci, czyli w postaci rękopisów, należy do rzadkości ${ }^{18}$. W wypadku dalszych badań nad epistolografią więzienną korzystanie z oryginałów wydaje się nieuniknione. Dostępne nam wybory więziennej korespondencji, z wyjątkiem wydanych w 2018 roku Listów z Cytadeli ${ }^{19}$ Bronisławy Waligórskiej, nie oddają materialnego charakteru więziennego listu. Dopiero całościowa, a zatem uwzględniająca nie tylko tekst, ale i wyglą $\mathrm{d}^{20}$, analiza rękopisów pozwoli w pełni zrozumieć charakter więziennej korespondencji. Niewątpliwie można stwierdzić, że list więzienny - podobnie jak dziennik - ,jest rzeczą materialną, w której tekst został zapisany" i już jako sam przedmiot jest obdarzony znaczeniem ${ }^{21}$.

W liście więziennym z pewnością częściej mamy do czynienia z tym, co Rodak w odniesieniu do dzienników nazywa „sytuacjami ekstremalnymi”. Ma on tu na myśli sytuacje, w których dzienniki zapisywane są nie na tradycyjnym papierze, lecz na przykład na kawałkach drewna, tekturze czy bibułce ${ }^{22}$. Pewną „swobodę” wyboru nośnika tekstu (paradoksalnie wynikającą z braku swobody innego typu komunikacji) mieli przede wszystkim autorzy grypsów, rzadziej listów legalnych, które pisane były głównie na kartce papieru wydanej przez służbę więzienną.

Oczywiście na wygląd więziennej korespondencji ogromny wpływ ma cenzor. Niezależnie od tego, czy cenzorskie skreślenia uznamy za przykład niszczenia listu więziennego ${ }^{23}$, czy - traktując niechcianego współautora nieco łaskawiej - przyjmiemy, że są one integralną częścią i nieodzowną właściwością

16 Ocenzurowane..., dz. cyt., s. 7.

17 G. i J. Kuroniowie, dz. cyt., s. 44.

18 P. Rodak, Między zapisem a literaturą. Dziennik polskiego pisarza XX wieku (Żeromski, Natkowska, Dąbrowska, Gombrowicz, Herling-Grudziński), Warszawa 2011, s. 56.

19 Warto zwrócić szczególną uwagę na edycję listów Waligórskiej, w której starano się w miarę możliwości oddać materialny wygląd korespondencji, między innymi pozostawiono skreślenia i podkreślenia autorki, jak również ingerencje cenzury więziennej. Zob. B. Waligórska, Listy z Cytadeli 1886, oprac. M. Rudaś-Grodzka, Warszawa 2018.

20 Oprócz badania wyglądu listów więziennych warte rozważenia jest też sięgnięcie po narzędzia analizy grafologicznej czy psychologicznej. Pisze o tym w odniesieniu do dzienników P. Rodak. Zob. tenże, dz. cyt., s. 60.

21 Tamże, s. 60-61.

22 Tamże, s. 58.

23 Myśl tę podsunął mi fragment książki P. Rodaka. Zob. tamże, s. 59. 
tego typu listu, nie możemy nie poddać refleksji tych wszystkich materialnych śladów obecności cenzora.

Materialność więziennej korespondencji ma więc ścisły związek z licznymi ograniczeniami formalnymi, do jakich musieli się dostosować autorzy, ale ujawnia się w niej także fizyczna obecność cenzora. Listy, które docierały do adresatów, nosiły materialne ślady ingerencji cenzury. Nieprawomyślne sformułowania czy nazwiska zamalowywano czarnym tuszem ${ }^{24}$ lub - jeśli postanowiono dać autorowi jeszcze jedną szansę - podkreślano czerwonym flamastrem $^{25}$. Materialnym śladem „opieki” cenzury nad korespondencją był też czerwony stempel przybijany na liście. Tak opisuje wygląd listu po ocenzurowaniu, z właściwą sobie ironią, Bielecki:

W prostokątnym stemplu przy napisie CENZUROWANO - z lewej strony „Made in Israel”, nad: „Ciebie i Marysię”, pod: „Mocno ściskam”, a przy rubryce podpis prokuratora widnieje: Tata $^{26}$.

Ingerencja cenzury utrudniała zarówno proces pisania listów, jak i ich lekturę. Zamazane czarnym tuszem fragmenty z pewnością budziły domysły, ale i niepokój czytelnika, ożywiały jego intuicję i wyobraźnię. W liście z 2 czerwca 1968 roku Kuroń informuje żonę o stanie listów, jakie od niej otrzymał: „Jak się zapewne domyślasz z tego pierwszego zdania, dostałem Twoje dwa listy z 16 i 20 maja - niestety numery były skreślone, jak i znaczna część treści”" Taki stan rzeczy doprowadził Kuronia do przekonania, że listy więzienne spełniają bardziej funkcję symboliczną (fatyczną) niż komunikacyjną. List z więzienia, w odróżnieniu od każdej innej korespondencji, wyróżnia się więc tym, że już sam w sobie stanowi niezwykłą wartość dla adresata. Dla więźnia bardzo ważna jest regularna korespondencja - nie tyle treść listu, ile samo jego istnienie jako rzeczy materialnej, możliwość jego dotknięcia itd. List jako namacalny znak obecności i solidarności bliskich osób przedstawia bowiem wartość samą w sobie.

Objętość listu również podlegała ścisłym restrykcjom. Więźniowi przysługiwała jedna kartka papieru kancelaryjnego ${ }^{28}$, co poważnie wpływało nie tylko na wygląd listu, ale przede wszystkim na jego treści i kompozycję. Ponadto list musiał być napisany starannie, czytelnie, z zachowaniem wyraźnych odstępów.

${ }^{24}$ J. Chwastyk-Kowalczyk, Cenzurowanie korespondencji w okresie stanu wojennego [w:] Nie po myśli wtadzy. Studia nad cenzura i zakresem wolności stowa na ziemiach polskich od wieku XIX do czasów wspótczesnych, red. D. Degen, M. Żynda, Toruń 2012, s. 367.

25 Zob. C. Bielecki, dz. cyt., s. 11

26 Tamże, s. 21.

${ }^{27}$ G. i J. Kuroniowie, dz. cyt., s. 154.

${ }^{28} \mathrm{O}$ tym, że pisma przekraczające przepisową długość były zwracane, pisał w jednym z listów Kuroń. Zob. G. i J. Kuroniowie, dz. cyt., s. 110. 
Listy pisane maczkiem były odsyłane z powrotem do przepisania. Zdarzały się sytuacje, gdy do listu dołączano zdjęcia, rysunki czy repertuary teatralne. Oczywiście i one poddawane były ścisłej kontroli, a często nawet rekwirowane bez wskazania przyczyny. Nie zawsze też listy pisane były na kartkach papieru. Tolerowano mniejsze formaty, takie jak pocztówki. Był to skuteczny sposób na kontakt z osadzonym w myśl zasady, że im krótsza wiadomość, tym większa szansa na przejście przez cenzurę bez skreśleń, a także alternatywna graficzna forma komunikacji. Przykładem tego typu wykorzystania graficznej strony listu do przekazania informacji więźniowi była pocztówka z wizerunkiem obrazu Teodora Axentowicza Poselstwo polskie u Henryka Walezjusza, co miało być aluzją do trwającej wówczas kampanii wyborczej do Sejmu ${ }^{29}$. Innym pomysłem na głębszy emocjonalnie kontakt z bliską osobą wykazał się Bielecki - z wykształcenia architekt - który odrysował swoją dłoń na kartce, kiedy indziej zaś wysłał swojej żonie autoportret ${ }^{30}$. Również Gaja do listów do męża dołączała rysunki ich syna Maćka oraz ich fotografie ${ }^{31}$.

Ograniczenia w wyborze adresata. Kolejnym nałożonym przez instytucję cenzury obostrzeniem była konieczność wyboru adresata, z którym decydowano się prowadzić korespondencję. Przypomnijmy, że więźniom przysługiwały zasadniczo dwa lub cztery listy na miesiąc. Bliskich osób, chcących kontaktować się z osadzonym, było zaś z pewnością znacznie więcej. Za jedną z praktyk radzenia sobie z tym ograniczeniem można uznać dopisywanie się osób trzecich do listu, co jednak nie zdarzało się często. Podczas pierwszego dłuższego pobytu w więzieniu Kuroń pod listami do Gai zapisywał drukowanymi literami informację dla wówczas kilkuletniego syna Maćka. Zasada ta działała i w drugą stronę - Maciek piórem matki pisał do ojca jedno czy dwa zdania. Ale w przypadku Kuronia taka praktyka stanowiła wyjątek. Do innych osób, na przykład ojca czy przyjaciół, Kuroń najczęściej zwracał się już pośrednio przez Gaję ${ }^{32}$. Ograniczenie liczby adresatów pociąga więc za sobą decyzję piszącego więźnia o wyróżnieniu jednej - zazwyczaj najbliższej - osoby, która ma się stać pośrednikiem między osadzonym a bliskimi. W przypadku Kuronia czy Bieleckiego - a także Havla - były to żony. Ta zasada w mniejszym stopniu obowiązywała osoby na wolności. Kilka osób mogło pisać do jednego więźnia. Widać to chociażby w zbiorze listów więziennych do Izabeli Jarosińskiej.

Co ciekawe, niekiedy powodem cenzorskiego skreślenia było już samo nazwisko osoby źle postrzeganej w oczach władzy. Dla przykładu w jednym

${ }^{29}$ Ocenzurowane..., dz. cyt., s. 21.

30 Zob. C. Bielecki, dz. cyt., s. 28, 64.

31 Zob. G. i J. Kuroniowie, dz. cyt., s. 27-28, 84.

${ }^{32}$ Kuroń, o czym wspominają autorki jego biografii, pisał też z więzienia listy do ojca. Było ich jednak - jak należy sądzić - nieporównywanie mniej niż listów do żony. Zob. A. Bikont, H. Łuczywo, Jacek, Warszawa 2018, s. 30. 
z listów do Jarosińskiej cenzor wykreślił imię i nazwisko Leszka Kołakowskiego ${ }^{33}$. Jarosińska nigdy też nie otrzymała żadnego listu od Jacka Kuronia, mimo że, jak się okazało, ten pisał do niej wielokrotnie. Trudno w tym wypadku jako przyczynę tego stanu rzeczy wymienić nieznajomość zasad „sztuki epistolarnej”, dlatego należy przypuszczać, że powodem wstrzymania korespondencji była sama osoba autora. W opublikowanej korespondencji więziennej Izabeli Jarosińskiej obecność Kuronia jako jednego z nadawców symbolizują pozostawione białe niezapisane strony ${ }^{34}$.

Tematyka listów. Ograniczenia tematyczne są chyba kwestią nie tylko najobszerniejszą do zanalizowania, ale i najtrudniej uchwytną pośród wszystkich wymienionych tu i opisanych restrykcji. Brak tu po prostu ścisłych wytycznych, o których więźniowie byliby poinformowani. Trzeba bowiem pamiętać, że za instytucją cenzury kryły się konkretne osoby dokonujące zmian i skreśleń w listach. Nietrudno więc będzie się zgodzić z Jolantą Chwastyk-Kowalczyk, która w artykule Cenzurowanie korespondencji w okresie stanu wojennego jako ważne czynniki funkcjonowania cenzury wymieniła osobowość i inteligencję osoby cenzora ${ }^{35}$. $Z$ pewnością nie bez znaczenia był też osobisty stosunek cenzora do osadzonego. Mając to na uwadze, warto na podstawie znanych przykładów korespondencji więziennej spróbować sporządzić i krótko omówić kanon tematów w niej zawartych. Z pewnością więzień polityczny musiał prowadzić tu grę z cenzurą, umiejętnie szyfrować lub bezpiecznie przemilczać nie tylko te tematy, które narażą go na jej ingerencję, ale także te, które dla cenzora, funkcjonariusza służby więziennej, mogły być cenne. Znający więc sztukę epistolografii więziennej autor takiego listu powinien niczym lekarz kierować się podstawową zasadą primum non nocere - po pierwsze: nie szkodzić. Wiedział o tym biegły w tej sztuce Kuroń, który ostrożnie pisał o współtowarzyszach z celi oraz unikał tematów związanych z funkcjonowaniem państwa ${ }^{36}$. Również Bielecki, nauczony rozlicznymi ingerencjami cenzury, w pewnym momencie wiedział już, o czym nie może pisać, dyskretnie tylko nadmieniając, że jest to temat „na potem” ${ }^{37}$. Potwierdza to skuteczność cenzorskiej „dydaktyki”.

Zasadniczo cenzurę więzienną - jak i każdą inną - możemy podzielić na polityczną i obyczajową. Z oczywistego względu nie można było pisać wprost o bieżącej sytuacji politycznej, a pisanie o niej za pomocą języka ezopowego, aluzji czy kodowanie tego typu informacji za pomocą metafor - obarczone było pewnym ryzykiem. W trakcie pierwszej odsiadki w jednym z listów Kuroń

33 Ocenzurowane..., dz. cyt., s. 92.

34 Zob. tamże, s. 145.

35 J. Chwastyk-Kowalczyk, dz. cyt., s. 374-375.

36 Zob. G. i J. Kuroniowie, dz. cyt., s. 235, 240.

37 Zob. C. Bielecki, dz. cyt., s. 79. 
nadmienia, że został zganiony przez cenzora za „niepotrzebną filozofię” ${ }^{38}$. Możemy tu przypuszczać, że owa „zbędna filozofia” była raczej z gatunku tej politycznej niż egzystencjalnej. Bieleckiemu zaś cenzura wytknęła komentowanie prasy czy prezentowanie fałszywego obrazu warunków więziennych. Jak się jednak okazuje, więzienna cenzura stała na straży poprawności nie tylko politycznej, ale i obyczajowej. Świadomość ograniczeń w tym zakresie miał Bielecki, gdy w jednym z listów do żony tłumaczył jej powstrzymywanie się od podejmowania tematów erotycznych ${ }^{39}$. Nie chodzi tu zapewne tylko o nietolerancję cenzury na tego typu wątki, ale i deprymującą świadomość piszących, że jest się „podglądanym”.

Wymienione tu tematy nie wyczerpują praktyk cenzorskich ingerencji. Przykładem cenzorskiego przewrażliwienia może być usunięcie z jednego z listów do Jarosińskiej zupełnie apolitycznego i jak najbardziej przyzwoitego fragmentu o książkach i węglu na zimę ${ }^{40}$. Dlatego odpowiadając na pytanie o to, jakie treści mogły się cieszyć szczególnym zainteresowaniem cenzury, należy stwierdzić - niemal wszystkie. Łatwiej wskazać, jakie tematy były „bezpieczne”, to znaczy cieszyły oko cenzora. Z pewnością zagadnieniem chętnie omijanym przez rękę „weryfikatora” były oznaki złego stanu psychicznego. Wiele takich fragmentów znajdziemy w listach Gai do męża. Do stałych tematów w przypadku osadzonego należą w pierwszej kolejności sprawozdania z pobytu w więzieniu, natomiast w przypadku osoby piszącej list do więzienia - opisywanie jej życia i losów najbliższych. Niekiedy opowieści więźniów dotyczą koegzystencji z innymi osadzonymi. Opisywanie codzienności nie tylko ma zastępować rozmowę, lecz przede wszystkim służyć tworzeniu więzi, wspólnoty i jedności. Dostrzec tu można jedną z rudymentarnych funkcji epistolografii więziennej, polegającą na budowaniu wspólnego życia w momencie, gdy fizycznie jest to niemożliwe. Listy Gai i Jacka Kuroniów są tego chyba najdobitniejszym przykładem. Kuroń za pomocą wymiany korespondencji z żoną pośrednio uczestniczył w wychowaniu syna, zaś Gaja - odpowiadając na bieżące przemyślenia męża - brała udział we współtworzeniu (podobnie jak działo się to na wolności) jego koncepcji. List więzienny nie tylko służy wzajemnemu informowaniu się o życiu i samopoczuciu, ale i w pewien sposób stanowi płaszczyznę ponownego scalania myśli, uczuć, nastrojów i potrzeb - tworzy przestrzeń wspólnej pracy. Aby pomimo rozłąki być ze sobac, Kuroniowie na przykład starali się czytać te same książki i dyskutować o nich na łamach listów. Nad tym, co praktykowali Kuroniowie, zastanawiał się Bielecki, dochodząc do przekonania, że literatura w więzieniu zwiększa łączność między ludźmi, przeciwdziała więc temu, co jest celem systemu karnego i jego decydentów - izolacji osadzonego ${ }^{41}$.

\footnotetext{
${ }^{38}$ Zob. G. i J. Kuroniowie, dz. cyt., s. 92.

39 Zob. C. Bielecki, dz. cyt., s. 28.

40 Zob. Ocenzurowane..., dz. cyt., s. 136.

${ }^{41}$ C. Bielecki, dz. cyt., s. 14.
} 
Innym ważnym tematem, pozostającym zresztą w związku z tym, o czym pisałem wyżej, jest problem psychicznego radzenia sobie z odosobnieniem i rozłąką. Mamy tu z jednej strony do czynienia z częstym opisem psychicznych reakcji i emocji będących wynikiem odosobnienia, z drugiej teoretyczne rozważania nad sposobami radzenia sobie z tymi „depresjami” . Podstawową receptą na przetrwanie jest pozbycie się myśli o rychłej możliwości wyjścia na wolność. Obecne jest to $\mathrm{w}$ wielu listach pisanych $\mathrm{w}$ ciągu lat. W jednym $\mathrm{z}$ listów do żony Bielecki stwierdził: „nadal siedzimy po to, aby siedzieć, a nie po to, aby wyjśćc" 42 . Podobne słowa znajdziemy w więziennych listach Iredyńskiego z lat sześćdziesiątych, który do żony Maszy pisał o braku nadziei na szybkie wyjście z więzienia jako o sposobie radzenia sobie z doświadczeniem pozbawienia wolności ${ }^{43}$. Jeszcze inny cytowany w artykule Chwastyk-Kowalczyk więzień z okresu stanu wojennego twierdził że „trzeba odpędzać od siebie mary wolności i jej najlepsze chwile" ${ }^{44}$. Najpełniej o tej teorii wypowiadał się Kuroń. Robił to nie tylko ad hoc w swoich listach, ale i w późniejszych książkach wspomnieniowych. I on oddalał od siebie myśli o wyjściu na wolność, gdy w jednym z pierwszych listów do żony pisał, że „cała sztuka [odsiadywania wyroku - dop. G.B.] polega na tym, aby żyć czasem teraźniejszym" ${ }^{45}$. W stanie wojennym, gdy żona dzieliła jego los, Kuroń przestrzegał ją: „Pod żadnym, ale to żadnym pozorem nie wolno przeżywać swojego uwolnienia” ${ }^{46}$. Inne recepty na psychiczne przezwyciężenie więziennej izolacji oraz samotności to oddanie się pracy intelektualnej, lektura książek, prowadzenie notatek czy nauka języków. Jeszcze innym sposobem, który sugeruje Kuroń w swoich listach, jest nabranie dystansu do obecnej sytuacji i potraktowanie jej jako epizodu przejściowego ${ }^{47}$. Chodzi tu, jak myślę, o nieuleganie rzeczywistości więziennej, spojrzenie na swoje życie i obecną sytuację z dystansu, z perspektywy całego życia.

Upływ więziennego czasu to kolejny temat, nad którym zastanawiają się więzienni epistolografowie. $Z$ perspektywy lat pisze też o tym inny więzień polityczny okresu PRL, Karol Modzelewski:

Martwota więziennego czasu polega na tym, że jest on nieruchomy. Nie płynie, nie przyspiesza, nie zwalnia, tylko stoi jak woda w stawie. Nie trzeba mieć nawyku filozofowania, żeby to zauważyć. Więźniowie - również ci niewykształceni - wyrażają to opisowo - dzień w tym miejscu nie różni się niczym od innych spędzonych tu dni ${ }^{48}$.

42 Tamże, s. 77.

43 I. Iredyński, Listy z więzienia, wybór, oprac., wstęp, przypisy i posłowie M. Sołtysik, Warszawa 2015, s. 137.

44 J. Chwastyk-Kowalczyk, dz. cyt., s. 377.

45 G. i J. Kuroniowie, dz. cyt., s. 20.

46 Tamże, s. 273.

47 Tamże, s. 163.

48 K. Modzelewski, Zajeździmy kobytę historii. Wyznania poobijanego jeźdźca, Warszawa 2013, s. 194. 
Również Bielecki skarżył się na „chorobę więzienną”, jaką ma być słabo odczuwalny upływ czasu ${ }^{49}$. Dla wyżej cytowanego sposobem radzenia sobie z monotonią więziennego życia było oddanie się pracy naukowej. Jego śladem podąża myśl Kuronia, dla którego praca była czynnikiem normalizującym upływ więziennego $\mathrm{czasu}^{50}$. Ale czas odmierzany jest przede wszystkim listami. Pomaga w tym regularność prowadzonej korespondencji. Każdy z listów - o ile otrzymywane są one regularnie - przynosi pozytywną wiadomość o skracającym się czasie rozłąki. Uwidacznia się tu kolejna funkcja listu więziennego. Staje się on w więziennej rzeczywistości punktem orientacyjnym upływającego czasu.

Pobyt w więzieniu stwarza też możliwość skupienia się na wcześniejszych zainteresowaniach osadzonych. A zatem kolejnym ważniejszym tematem więziennej korespondencji będzie kontynuacja pracy i działalności osadzonych z okresów wolności. Wychowawca Kuroń nie tylko prowadził w więzieniu obserwacje swoich współtowarzyszy, ale i pracował nad doktoratem. Bielecki, z wykształcenia architekt, rysował i „bawił się” (gdyż pracować nie mógł) w projektowanie miasta. Jak się wydaje na podstawie choćby listów ich obu, odosobnienie sprzyja też zachowaniom religijnym czy quasi-religijnym. Przebywający przez pewien czas w celi z buddystą Bielecki w pewnym momencie nadmienia o „świeckiej modlitwie”, którą odprawiał w skupieniu, siedząc w pozycji półlotosu $^{51}$. Podobnie Kuroń: medytował, czytał Biblię, a swoje myśli o żonie nazywał modlitwą. Uczestniczył również w mszach, a także zastanawiał się nad filozoficznymi i etycznymi podstawami chrześcijaństwa.

Jeszcze innym wątkiem pośrednio obecnym w listach, a służącym podtrzymywaniu, budowaniu czy rozwijaniu więzi emocjonalnych, jest prowadzenie wyobrażonych rozmów między korespondującymi. Ta alternatywna i poniekąd symboliczna forma komunikacji ma ważne znaczenie. Wyobraźnia nie jest skrępowana tymi wszystkimi ograniczeniami, którymi skrępowany jest list: więcej można pomyśleć niż napisać w liście. Konieczność stworzenia tego typu wyobrażonych „spotkań” z drugą osobą potwierdza to, co sygnalizował Bielecki, mianowicie: że list z więzienia, choć stanowi ważny i nieodzowny element życia więziennego, jest zarazem ułomnym nośnikiem treści. Oprócz rozmów prowadzone są - częściowo dla zabicia czasu, częściowo dla poprawy samopoczucia - gry wyobraźni. Bielecki wraz ze swoim towarzyszem układali menu, które chcieliby zjeść na wolności. Innym razem Bielecki wyobrażał sobie, że je z żoną wykwintną kolację ${ }^{52}$.

Równie ważnym tematem korespondencji więziennej, a zarazem tym, od którego pewnie powinno się zacząć, są uczucia. Dyskurs miłosny nierozerwalnie łączy się w korespondencji więziennej z uczuciami smutku, przemożnej

\footnotetext{
${ }^{49}$ Zob. C. Bielecki, dz. cyt., s. 15-16.

${ }^{50}$ Zob. G. i J. Kuroniowie, dz. cyt., s. 64.

51 Zob. C. Bielecki, dz. cyt., s. 67.

52 Zob. tamże, s. 49, 63.
} 
tęsknoty, oczekiwania, ale i epifanii miłosnych wyznań. Polska cenzura więzienna stojąca na straży „praworządności” zarówno politycznej, jak i obyczajowej zapewne tylko sporadycznie ingerowała $\mathrm{w}$ dyskurs miłosny zawarty w listach więziennych, skoro otrzymaliśmy jeden z najpiękniejszych literackich dowodów szczerej i bezgranicznej, choć niełatwej z uwagi na czynniki zewnętrzne miłości, którym jest niewątpliwie korespondencja Gai i Jacka Kuroniów. Trudno tu nawet porównywać listy Kuroniów z tymi Bieleckiego, który, jakkolwiek pisze o miłości, czyni to dużo dyskretniej i - w stosunku do Kuroniów - o wiele skromniej. Niemniej nie wszyscy więzienni epistolografowie decydują się na włączenie tematyki miłosnej do listów; Vaclav Hacel jej nieobecność w swoich listach tłumaczy brakiem intymności, spowodowanym świadomością bycia "podglądanym” przez cenzora ${ }^{53}$.

Do charakterystycznych cech więziennych korespondencji należy ich autotematyzm. Wszak jednym z tematów listów więziennych są właśnie one same. Pierwszym przejawem owego automatyzmu mogą być rozważania teoretyczne nad istotą samego listu, drugim - psychologiczne zmagania z procesem pisania listu więziennego. Praca więziennej cenzury to, jak słusznie zauważyła Gaja Kuroń, szukanie podtekstów i sygnałów ${ }^{54}$. Pisanie tak, aby zminimalizować ryzyko znalezienia fragmentów dających cenzorowi prawo ingerencji, rodziło w piszących poczucie bezsensu i pustki. Częste są więc narzekania na „zmęczenie materiału", odkładanie pisania listu na później czy świadomość, że treść listów traktuje o rzeczach błahych. Budzą one agresję wymierzoną w cenzurę. Zresztą cenzura prowokuje nie tylko nienawiść, ale i obawę przed szczerością. Problem ten w szczególny sposób dotykał Gaję Kuroń, która, komentując jeden ze swoich listów do Jacka, stwierdziła, że nie zgadza się z tym, co napisała. Nie widząc jednak wyjścia z tej sytuacji, nie zdecydowała się na korektę. Kuroniowa była szczególnie krytyczna wobec siebie i swoich listów. Zarzucała sobie między innymi schematyzm ${ }^{55}$. Trudny był dla niej już sam moment pisania. Nie panowała przy tym nad emocjami, co zauważył jej mąż. Kuroń, porównując dwa listy od żony, charakteryzował jeden jako „list człowieka bardzo silnego”, drugi zaś jako list „biednej, zakochanej dziewczyny” ${ }^{66}$. Miał jednak dużo lepsze zdanie o jej listach niż ona sama. Charakteryzował je jako „piękne, mądre i szczere" 57 . Również Bielecki wspominał z jednej strony o przyjemnym aspekcie pisania listów do żony: „dotykając długopisem papieru, zaczynam czuć Twoje ciepło i obecność" 58 . Jednak w momentach, w których nie dawał się ponieść emocjom, rzeczowo nadmieniał o trudnościach związanych

53 Zob. V. Havel, Listy do Olgi (czerwiec 1979 - wrzesień 1982). Wybór, wybór i wstęp J. Baluch, tłum. E. Szczepańska, Warszawa, Wrocław 1993, s. 22

${ }_{54}$ Zob. G. i J. Kuroniowie, dz. cyt., s. 119.

55 Tamże, s. 34, 49.

56 Tamże, s. 94.

57 Zob. tamże, s. 63.

58 C. Bielecki, dz. cyt., s. 23. 
z tego typu zajęciem, między innymi o tym, że pisanie listów jest zajęciem czasochłonnym i kosztuje wiele wysiłku ${ }^{59}$.

Gra z cenzurą jest istotnym elementem więziennych korespondencji. Okazuje się, że swoje miejsce w tej grze ma również literatura. Czytane przez więźniów powieści czy pozycje naukowe bardzo często mają wiele wspólnego z sytuacją osadzonego. Książki te zostają wplecione w przebiegłą grę z cenzurą w ten sposób, że mają mówić to, czego nie da się przekazać za pomocą listu. Tak dzieje się choćby przy okazji lektury Ptomieni Stanisława Brzozowskiego:

Jest w tej książce wszystko, co chciałbym Ci powiedzieć, a czego nie zamierzam na tych kartkach. Proszę, przeczytaj jeszcze raz Płomienie tak, jakbyś czytała list ode mnie. (...) Proszę bardzo, przeczytaj to jeszcze raz, kiedy będzie Ci smutno, pusto, tęskno. Zobaczysz, ta książka Ci pomoże ${ }^{60}$.

To właśnie te z pozoru niewinne fragmenty, w których piszący dzielą się refleksjami z przeczytanych książek, mogą nieść w sobie trudną na pierwszy rzut oka, ale jakże ważną informację o rzeczywistych myślach autora. Pełnią więc funkcję osobistego kodu kulturowego, często niedostępnego dla cenzora. Warto też zauważyć, że w sytuacji uwięzienia bliscy stają się autorzy, którzy w przeszłości doświadczyli losu więźnia ${ }^{61}$.

Innym sposobem kodowania informacji będzie metafora. Na przykład Bielecki stworzył alegorię Wysokiej Szuflady na określenie tajemniczego miejsca, „poczekalni”, do której trafiają listy zatrzymane przez cenzurę ${ }^{62}$. Zaś Kuroń, aby pomóc żonie zrozumieć, dlaczego mimo sytuacji uwięzienia ma tak dobry nastrój, stworzył metaforę elewacji ${ }^{63}$. Chowający się za „elewacją”, zatem udający w listach do żony pogodnego i zadowolonego człowieka, Kuroń przyczynił się w ten sposób do powstania pewnego nieporozumienia między nim a Gają. W niej bowiem, jak wynika z listu Kuronia, strategia udawania dobrego samopoczucia budziła więcej obaw niż - jak było to w zamiarze autora - spokoju. Pokazuje to, że metafory bywały źródłem nieporozumień, nie tylko między osadzonym a bliskim na wolności, ale i między cenzorem a jednym z piszących. Tak dzieje się, gdy jeden z listów Gai zostaje wstrzymany za metaforyczne użycie słowa „tortura” ${ }^{64}$. Przykład ten świetnie oddaje też językowe ograniczenia więziennej korespondencji.

59 Zob. tamże, s. 81-82.

60 G. i J. Kuroniowie, dz. cyt., s. 200.

61 Bielecki przywołuje w pewnym momencie wiersze Osipa Mandelsztama, zob. C. Bielecki, dz. cyt., s. 107.

62 Zob. tamże, s. 73.

63 Zob. G. i J. Kuroniowie, dz. cyt., s. 78.

64 Powody wstrzymania tego listu przywołuje Kuroń, zapewne poinformowany o tym przez służbę więzienną. Zob. tamże, s. 122. Nieco później pisze o tym nie bez irytacji Gaja: 
Autorzy listu więziennego posługiwali się też - na dużo większą skalę i w gruncie rzeczy jawnie - inną bronią: aluzją czy ironią. Było to rzecz jasna ryzykowne, co potwierdza konfiskata listów Bieleckiego przez prokuratora. Zarzucono mu wówczas właśnie postawę ironiczno-aluzyjną ${ }^{65}$. Jednak w listach nie brak mniej lub bardziej subtelnych aluzji, które nie doczekały się skreśleń cenzora. Co ciekawe, w dużej mierze dotyczyły one właśnie potyczek autora z cenzurą. Mistrzem ironii oraz odwagi w posługiwaniu się nią był właśnie Bielecki $^{66}$. Ale i Kuroń w trakcie swojej pierwszej dłuższej odsiadki w 1965 roku rozpoczyna korespondencje do żony w pełni świadomy, że odtąd ironia będzie mu stale towarzyszyć przy pisaniu listów:

Jak tu jest? No trudno powiedzieć, że dobrze, ale w każdym razie można żyć. Jem (na koszt państwa), śpię (w państwowej pościeli), palę (sąsiedzi z celi mają papierosy), no i oczywiście prowadzę bardzo miłe konwersacje z funkcjonariuszami państwowymi ${ }^{67}$.

Nie można nie wspomnieć też o języku ezopowym, starej i znanej strategii omijania cenzury przez literaturę piękną. Jak jej status przedstawia się w epistolografii więziennej? Istnieją dwie możliwości: albo nie jest ona zbyt często używana, albo jako niewprawni czytelnicy nie dość wyraźnie dostrzegamy ukryte w niej sensy. Kilka przykładów mowy ezopowej znajdziemy we fragmentach listów wysyłanych do Izabeli Jarosińskiej, która zresztą w przypisach wyjaśnia czytelnikom ich znaczenie. Bez tego przynajmniej niektóre aluzje byłyby nieczytelne. Kiedy w jednym z otrzymanych w celi listów pojawia się stwierdzenie: "pogoda zmienna, ale robi się ciepło i to jest nadzieja”, przypis wyjaśnia, że tak naprawdę chodziło o sytuację polityczną w kraju ${ }^{68}$. Innym razem Magdalena Klemm wspomina w liście, ot tak, o „torcie bezowym”, który „był chyba ostatnim tortem”, a Jarosińska dopowiada w przypisie, że fragment ten był aluzją do aresztowania między innymi Zbigniewa Bujaka ${ }^{69}$. Inny przykład mowy ezopowej, opartej na zabawnej grze słów wykorzystującej homonimię wyrazów, znajdziemy w tym samym krótkim liście Klemm do Jarosińskiej, który przytacza też Jan Olaszek w biografii Jana Walca: „Za to w Kolonii będzie turniej tańca to-

„Jak można czepiać się słów, nie rozumiejąc kontekstu. Przecież słowo »tortura« jest cholernie względne, a sam fakt pozbawienia wolności można określić w ten sposób, nie dopatrując się w tym niczego więcej”. Zob. tamże, s. 124.

65 Zob. C. Bielecki, dz. cyt., s. 24.

${ }^{66} \mathrm{Na}$ przykład kiedy w jednym z listów Bielecki, opisując swój rysunek umieszczony dla żony, z ironią odnosi się do pracy cenzora: „A tak swoją drogą, gdyby nie dwie »firanki«, siatka i blinda, to okno rzeczywiście jest tu jak w klasztornej celce. (Znając wyczulenie cenzorów na aluzje, nie rysuję Ci krat)". Zob. tamże, s. 30.

${ }^{67}$ G. i J. Kuroniowie, dz. cyt., s. 19.

${ }^{68}$ Ocenzurowane..., dz. cyt., s. 13.

${ }_{99}$ Zob. tamże, s. 229-230. 
warzyskiego niemieckiego i innych narodowości i pojedziemy zobaczyć przede wszystkim walca”"70. Chodzi tu, rzecz jasna, o wyjazd Walca za granicę. Coś na kształt języka ezopowego pojawiło się również w liście Gai do Jacka z 24 sierpnia 1969 roku: „W Warszawie atmosfera straszna, same pożegnania”71. Jest to aluzja do konsekwencji Marca '68, którym była przymusowa emigracja osób pochodzenia żydowskiego, w tym przyjaciół Kuroniów. O interesującym przykładzie mowy ezopowej pisze też Olaszek we wspomnianej już książce, gdzie cytuje słowa Joanny Trzeciak-Walc (żony Jana Walca), streszczającej fragment listu od męża internowanego w czasie stanu wojennego:

A drugie zamówienie, jakie mąż mój złożył, było takie, że zamierzają drukować pismo, żebym przywiozła mu to wszystko, czego Mirek potrzebował, jak był u nas w domu. To ja doskonale wiedziałam, że chodzi o pokost i farbę. Jak on powiedział, że chce dżemu z czarnej porzeczki, to ja doskonale wiedziałam, czego on chce [farby drukarskiej] ${ }^{72}$.

Wydaje się więc, że język ezopowy funkcjonuje w listach więziennych, jednak jest on dziś mało czytelny dla osób niebiorących udziału w tamtych wydarzeniach oraz nieposługujących się „slangiem” opozycjonistów w PRL, więźniów politycznych. W jego zrozumieniu niezbędne są więc przypisy lub objaśnienia samych autorów czy odbiorców listów.

\section{Podsumowanie}

Z powyższej analizy cenzorskich rygorów, z jakimi musieli się borykać autorzy listów więziennych wynika kilka ważnych, choć ogólnych, wniosków. Przede wszystkim cenzor nie tylko nadzoruje, ale i w znaczny sposób uczestniczy w procesie pisania listów (współtworzy je). Dla literaturoznawców oznacza to ni mniej ni więcej, że jest ich współautorem. Fakt ów powoduje nie tylko osłabienie intymnego charakteru listów, ale i pozbawia list więzienny ważnych cech literatury dokumentu osobistego - autobiograficznej szczerości i intencji „odsłonięcia się". Tej możliwości nie oferuje epistolografia więzienna, mało tego, stwarza ona fałszywy, z pozoru niegroźny obraz więziennej egzystencji osadzonego. To chyba podstawowy zarzut, jaki można w nią wymierzyć.

Analiza zmagań autorów listów więziennych z cenzurą dostarcza również innych ciekawych spostrzeżeń. Cenzorskie restrykcje - stawianie wymogów

${ }^{70}$ Cyt. za: J. Olaszek, Jan Walc. Biografia opozycjonisty, Warszawa 2018, s. 347. Por. Ocenzurowane..., dz. cyt., s. 229.

${ }^{71}$ G. i J. Kuroniowie, dz. cyt., s. 185.

${ }^{72}$ J. Olaszek, dz. cyt., s. 287. 
i ograniczeń - doprowadzają do tworzenia się między piszącymi pewnych zasad, które mają za zadanie pomóc w komunikacji, zatem naprawić to, co zaburza cenzura. Zasada numerowania listów, wysyłanie zdjęć i rysunków jako alternatywna forma komunikacji, tworzenie na odległość wspólnoty czytelniczej czy kodowanie informacji za pomocą nowych metafor - to wszystko pokazuje, że ci dwaj równorzędni autorzy wytwarzają między sobą pewną kulturę epistolografii, która jest tym lepsza, im bardziej wykluczony jest z niej trzeci autor - cenzor.

W niniejszej pracy, jak już pisałem na wstępie, posługiwałem się dość wąskim korpusem tekstów. Dlatego sądzę, że istnieje konieczność pogłębionej analizy opartej na większej liczbie świadectw więźniów politycznych PRL. Takie przyszłe opracowanie z pewnością dostarczy innych interesujących wniosków, niektóre z zaprezentowanych w niniejszym szkicu potwierdzi, inne być może obali. Jednym z wyzwań stojących przed badaczami więziennej epistolografii jest stworzenie typologii listów więziennych i jej zasadniczy podział na list typu legalnego i gryps, który omija przynajmniej niektóre z analizowanych tu ograniczeń. Grypsy, choć pozbawione bezpośrednich działań cenzora, nie są całkowicie wolne od cenzury instytucjonalnej. Autorom grypsów z pewnością towarzyszy świadomość możliwości przechwycenia nielegalnych listów przez nadzorców. Warto więc szukać odpowiedzi na pytania, które nasuwają się już po pobieżnych analizach legalnych listów z więzienia i grypsów: w jakim stopniu te ostatnie są tematycznie „pojemniejsze”, to znaczy w jakim stopniu ich autorzy pozwalają sobie na większą szczerość, intymność oraz co tak naprawdę sądzą o „niechcianym współautorze”?

Przed badaczami epistolografii więziennej stoi trudne zadanie. Jeśli chcemy stworzyć syntezę więziennej epistolografii, powinniśmy poddać analizie nie tylko to, co w niej zostało napisane, ale być może przede wszystkim odgadnąć to, co kryje się pod czarnym tuszem cenzorskiego skreślenia.

\section{Bibliografia}

Barańczak S., Horyzont absolutny [w:] tegoż, Tablica z Macondo. Osiemnaście prób wyttumaczenia, po co i dlaczego sie pisze, Londyn 1990.

Bielecki C., Z celi do celi. Listy do żony, Londyn 1990.

Bikont A., Łuczywo H., Jacek, Warszawa 2018.

Budrowska K., Literatura i pisarze wobec cenzury PRL (1948-1958), Białystok 2009.

Chwastyk-Kowalczyk J., Cenzurowanie korespondencji w okresie stanu wojennego [w:] Nie po myśli wtadzy. Studia nad cenzura i zakresem wolności stowa na ziemiach polskich od wieku XIX do czasów wspótczesnych, red. M. Degen, M. Żynda, Torun 2012.

Fik M., Cenzor jako wspótautor [w:] Literatura i wtadza, red. B. Wojnowska, Warszawa 1996. 
Havel V., Listy do Olgi (czerwiec 1979 - wrzesień 1982). Wybór, wybór i wstęp J. Baluch, tłum. E. Szczepańska, Warszawa, Wrocław 1993.

Iredyński I., Listy z więzienia, wybór, oprac., wstęp, przypisy i posłowie M. Sołtysik, Warszawa 2015.

Kuroniowie G. i J., Listy jak dotyk, Warszawa 2014.

Kuroń J., Wiara i wina. Do i od komunizmu, Warszawa 1990.

Modzelewski K., Zajeździmy kobytę historii. Wyznania poobijanego jeźdźca, Warszawa 2013.

Ocenzurowane. Listy do więzienia 1985-1986, wybór i oprac. I. Jarosińska, Warszawa 2012.

Olaszek J., Jan Walc. Biografia opozycjonisty, Warszawa 2018.

Pawlicki A., Kompletna szarość. Cenzura w latach 1965-1972. Instytucja i ludzie, Warszawa 2001.

Rodak P., Między zapisem a literatura. Dziennik polskiego pisarza w XX wieku (Żeromski, Natkowska, Dąbrowska, Gombrowicz, Herling-Grudzinski), Warszawa 2011.

Sam na sam z Polską Ludowa. Z cenzorem rozmawia J. Pruszyńska, „Rzeczpospolita”, 15-16.04.2000.

Waligórska B., Listy z Cytadeli 1886, oprac. M. Rudaś-Grodzka, Warszawa 2018. 